\title{
Dutch ENIG: from nonveridicality to downward entailment
}

\author{
Jack Hoeksema
}

Accepted: 10 August 2009 / Published online: 22 October 2010

(C) The Author(s) 2010. This article is published with open access at Springerlink.com

\begin{abstract}
In combinations with singular count nouns, the Dutch indefinite determiner enig 'some/any' shows a diachronic distributional shift from nonveridical environments in general to a strict subset thereof, namely negative, conditional and interrogative contexts. Similarities with Greek indefinites of the kanenas-series are explored, and an argument is given that at some point enig has split into two uses, one of which is currently on its way out. Nonemphatic, nonreferring enig is disappearing, whereas emphatic enig is stable within a set of environments similar to those of English any or ever.
\end{abstract}

Keywords Nonveridicality $\cdot$ Polarity $\cdot$ Diachronic change $\cdot$ Indefinite $\cdot$ Prosodic differentiation

\section{Introduction}

Many linguists have been intrigued by the complex distributional patterns displayed by negative polarity items. Some have tried to account for these in syntactic terms (e.g. Klima 1964; Progovac 1994; den Dikken 2002, 2006; ${ }^{1}$ Postal 2000, 2005), others in semantic/pragmatic terms (e.g. Fauconnier 1978; Ladusaw 1979;

\footnotetext{
${ }^{1}$ Both den Dikken's and Postal's papers are concerned with secondary, or parasitic licensing as well as ordinary licensing. In parasitic licensing examples, licensing of a polarity item $\mathrm{X}$ by a trigger $\mathrm{Y}$ is mediated by another polarity item Z (see also Hoeksema 2007).
}

Precursors of this paper were presented at the LOT Winterschool in Groningen, 2005, and at the Negation and Polarity Conference at the Eberhard Karls Universität in Tübingen, March 2007. I would like to thank the audience at that conference, as well as two anonymous reviewers, and Doris Penka and Hedde Zeijlstra for their comments, suggestions and criticisms. The blame for all errors and omissions, however, lies entirely with me.

J. Hoeksema $(\varangle)$

CLCG, University of Groningen, P.O. Box 716, 9700 AS Groningen, The Netherlands

e-mail: j.hoeksema@rug.nl 
Zwarts 1981, 1998; Kadmon and Landman 1993; Krifka 1995; Israel 1996; van der Wouden 1997; Lahiri 1998; Giannakidou 1998; von Fintel 1999; Chierchia 2006; Gajewski 2008), or a combination of both (e.g. Linebarger 1981). However, it seems evident, that these distributional patterns are determined by more than the semantic and syntactic requirements of the polarity items themselves.

One additional factor which should be considered is paradigmatic in nature, namely the presence or absence of competing elements. For instance, in many Slavic languages, indefinite polarity items are found in all contexts in which polarity items may normally be found, except one: direct clause-mate negation (Progovac 1994; Pereltsvaig 2006). This may seem surprising, given that negation is presumably the prototypical environment for polarity items. Pereltsvaig calls this the "bagel" problem: the distribution is that of negative polarity items, but with the central core missing. The apparent source of the bagel problem is the existence, in Slavic, of negative concord, which takes precedence over alternative types of exponence involving indefinite polarity items under the scope of negation. The missing core of the bagel is the result of some sort of blocking. More generally, it has been argued for by de Swart (2010) that negative concord and the expression of negation more generally call for an optimality-theoretic treatment, which compares various alternatives and selects the optimal one according to a set of ranked constraints. Jäger (2010) likewise assumes that the complementary distribution of any and some is due to competition. The item with the more narrowly circumscribed distribution, any, blocks the use of its more general counterpart some by virtue of the Elsewhere Principle (Kiparsky 1973). ${ }^{2}$

A final complicating factor which should be mentioned here is prosodic differentiation. It is clear from a number of investigations that stressed occurrences of polarity items may vary in their distribution from unstressed occurrences (Sahlin 1979; Giannakidou 1997; Hoeksema 1999). Giannakidou, for instance, shows that Greek kanenas, when stressed, appears in a small subset of the environments where its unstressed variant can be found, namely negation, clauses introduced by xoris 'without' or by prin 'before'. Sahlin, in an early study using a prosodically marked-up corpus of spoken English, notes substantial differences between stressed and unstressed occurrences of any. Hoeksema, finally, reports on several prosodic differences between

\footnotetext{
${ }^{2}$ While this type of explanation is certainly appealing, there are also some recalcitrant problems still waiting to be resolved. For instance, while the distribution of some and any is largely complementary, there are some areas of overlap as well. In conditionals, questions and other not strictly negative environments, either determiner is acceptable:
}

(i) Do you want some coffee?

(ii) Do you want any coffee?

The two questions are sometimes claimed to be pragmatically distinct (Borkin 1971; Ladusaw 1979), in that the latter, but not the former, question assumes a negative answer. However, the matter seems to be more subtle than that, and questions such as (ii) are certainly different from rhetorical questions. Likewise, environments of double negation are acceptable for both items as well (cf. Baker 1970, and for more contexts of double negation Szabolcsi 2004):

(iii) I can't believe that you don't want some coffee.

(iv) I can't believe that you don't want any coffee. 
polarity-sensitive and nonsensitive ooit 'ever' in Dutch (possibility of comma intonation (in the case of nonsensitive ooit) and possibility of emphatic lenghtening of the vowel (cf. for discussion of this phenomenon van Ommen et al. 2007) in the case of polarity-sensitive ooit), compare the following sentences, where the spelling $o-o-i-t$ indicates emphatic lengthening:
a. Ik geloof niet dat ik o-o-i-t zo gelachen heb.
I believe not that I ever so laughed have
'I don't believe I have ever laughed so much.'
b. Ik geloof dat ik ooit zo gelachen heb.
I believe that I once so laughed have
'I believe I have once laughed so much.'
c. *Ik geloof dat ik o-o-i-t zo gelachen heb.
I believe that I once so laughed have
'I believe I once laughed so much.'

In this paper I will discuss an almost completed change in the distribution of a Dutch polarity item, enig. I will argue that the narrowing of the distribution of this item is compatible with the hypothesis that the item has been reanalyzed from a nonreferential indefinite to a more emphatic type of indefinite with the property of pragmatic strengthening in the sense of Kadmon and Landman (1993). This reanalysis is accompanied by a change in distribution from nonveridical environments toward downward-entailing environments. The evidence on which the diachronic claims are based, comes from a collection of more than 100,000 occurrences of Dutch negative polarity items, collected by the author from various sources, including electronic texts such as the ones in the Digital Library of Dutch Literature and Language (see www.dbnl.org) and other Internet sources, the digital newspapers at the website of the Dutch Royal Library (www.kb.nl), but also from books and magazins read by the author over a long period. This collection is currently large enough to study diachronic changes in the more frequent polarity items, such as Dutch enig. ${ }^{3}$

\section{Dutch enig}

The West Germanic languages all have determiners derived from the numeral one by means of the affix -ig (which developed into - $y$ in English), compare German einig, Dutch enig, and English any (Old English aenig). While these determiners share a common origin, it is clear that they have developed in different directions. English any is now the best-known example of a negative polarity item, German einig is not a polarity item, and Dutch enig takes a middle position: it is a polarity item when combined with a singular count noun, and not polarity-sensitive with mass or plural nouns (cf. Hoeksema and Klein 1995). ${ }^{4}$ This general behavior is illustrated by the examples in (2):

\footnotetext{
${ }^{3}$ The data file used for the study of enig in this paper can be downloaded from my homepage (see http://www.let.rug.nl/hoeksema).

${ }^{4}$ English any shows a similar differentiation between singular count uses and plural/mass uses: Free choice any is restricted to singular count nouns. For instance, in the following sentences, only (i)a shows an
} 
(2)
a. We hebben enige tijd. ${ }^{5}$
We have some time
'We have some time.'

b. We hebben nooit enige tijd.

We have never any time

'We never have any time.'

c. We hebben enige problemen.

We have some problems

'We have some problems.'

d. We hebben nooit enige problemen

We have never some problems

'We never have any problems'

e. *We hebben enig probleem.

We have some problem

'We have some problem.'

f. We hebben nooit enig probleem.

We have never any problem

'We never have any problem.'

In English, any is a well-known polarity item, and shows up in the following collection of environments (cf. Klima 1964; Ladusaw 1979; Linebarger 1981; Horn 1989, 2000a, 2000b, 2005; Kadmon and Landman 1993; and much other literature):

ambiguity due to the difference between free choice and NPI any, whereas (i)b appears to only have the NPI reading:
a. If you like any apple, you will (even) like this one.
b. If you like any apples, you will (even) like these.

However, the English situation is complicated by the fact that in combinations with numerals, plural any may also have a free-choice reading (Carlson 1981):

(ii) Any four men will be able to lift this casket.

Israel (1999) notes that English some in its so-called spesumptive use, where the speaker cannot or will not specify the identity of the referent, is likewise restricted to singular count nouns. Hence (iii)a is rather odd, while (iii)b is just fine (examples from Israel 1999):

(iii) a. \#Noah rented some film for us to watch. It's an old favorite of mine: The Unbelievable Truth.

b. Noah rented some films for us to watch. They're old favorites of mine: Trust, Suspicion and The Maltese Falcon.

${ }^{5}$ One of the reviewers did not much like sentences a and c. Examples of this kind are well-attested, however. I believe that the reviewer's intuitions might reflect a certain preference (by no means absolute) to use enige problemen in negative contexts (about $50 \%$ of occurrences, according to a search of newspaper data from LexisNexis) and enige tijd as an adverbial, rather than a direct object, as in (1a). Note, however, that these preferences are neither of them very strong. Attested examples similar to (1a) and (1c) are:

(i) a. Omdat er weinig meer van het lichaam over is, zal de vaststelling van de Because there little more of the body left is, will the determination of the identiteit nog enige tijd in beslag nemen. identity still some time in seizure take 'Because there is little left of the body, the determination of the identity will take some more time.'

(De Telegraaf, 14-8-2008) 


\section{Negative Contexts}

a. Negative sentences

b. Questions

c. Protasis (=antecedent) of conditionals

d. Complements of negative ("adversative") predicates

e. Clausal complements of too

f. Complements of without

g. Complement of before 6

h. The scope of quasi-negative quantifiers such as little, few, seldom

i. Scope of XP modified by restrictive adverbs (only, hardly)

j. Relative clauses modifying universal or superlative noun phrases

k. Comparative clauses (both of equality and of inequality)

This set of environments is also characteristic of the distributional properties of modern Dutch enig and of English ever, provided we ignore for the moment those uses of ever where it signifies 'always': He was ever the same. Ever since the accident, he was a changed man (cf. Israel 1998 for discussion). It is the classical set of negative polarity contexts, often referred to as downward-entailing or monotone-decreasing contexts (cf. Ladusaw 1979; Zwarts 1981; van der Wouden 1997). ${ }^{7}$ Illustrations of enig in the various attested environments are given in (3) below, which mirrors the list in (3) above:

a. Geen van hen heeft enig dier geslacht. none of them has any animal slaughtered 'None of them has slaughtered any animal.'

b. Heeft $\mathrm{u}$ ooit enig voorstel verworpen?

Have you ever any proposal rejected 'Have you ever rejected any proposal?'

c. Als ik enig voorstel verwerp, wordt hij boos. When I any proposal reject, becomes he mad 'When I reject any proposal, he gets mad.'

b. Het college verwacht dat dit echter in de praktijk nog enige problemen kan opleveren. The college expects that this however in the practice yet some problem can create 'The college expects that this, however, may still cause some problems in practice.'

(Veluws Dagblad, 2-8-2008)

\footnotetext{
${ }^{6}$ Not all before-clauses permit polarity items, but only so-called nonveridical before (cf. Anscombe 1964; Landman 1991; Sánchez-Valencia et al. 1994, and for a somewhat different view, Condoravdi 2010).

${ }^{7}$ Actually, there are a number of well-known problems with the characterization of the contexts of any as downward-entailing. In particular, questions are a well-known problem (cf. Giannakidou 1998; van Rooij 2003) as well as restrictive adverbs such as only (Atlas 1996; von Fintel 1999; Giannakidou 2006), superlatives (Hoeksema 1986; von Fintel 1999), conditional clauses (Heim 1984; von Fintel 1999) etc. It is not my goal in this article to solve the problem of the semantic characterization of the distribution of any but rather to document a case of an indefinite polarity item that shows a shift in distribution from something very close to the kanenas-variety of polarity items (cf. Giannakidou 1997, 1998 and elsewhere) to that of English any. The title of the paper should be read with this cautionary note in mind.
} 
d. Hij ontkende enig dier geslacht te hebben.

he denied any animal slaughtered to have

'He denied having slaughtered any animal.'

e. Het was te koud om enig kledingstuk uit te doen.

It was too cold for any piece of clothing off to do

'It was too cold to take off any piece of clothing.'

f. Hij vertrok zonder enig voorstel verworpen te hebben.

he left without any proposal rejected to have

'He left without having rejected any proposal.'

g. Nog voor enige student iets kon zeggen, was de docent

Yet before any student something could ask, was the teacher

al verdwenen.

already gone

'Even before any student could say anything, the teacher had already left.'

h. Weinig mensen hebben enig voorstel ingediend.

Few people have any proposal submitted

'Few people have submitted any proposal.'

i. Alleen Jan gaf enig teken van leven.

Only Jan gave any sign of life

'Only Jan gave any sign of life.'

j. Iedereen die enig voorstel gedaan heeft, krijgt antwoord. everybody who any proposal done has, receives answer 'Everybody who has made a proposal, will receive an answer.'

k. Hij was langer dan / zo lang als enige andere speler.

He was taller than / as tall as any other player

'He was taller than / as tall as any other player.'

Unlike any, however, enig does not have a use as a free-choice item: ${ }^{8}$

(4) 1. *Neem een appel, enige appel.

Take an apple, any apple

'Take an apple, any apple.'

m. *Jan kan enig probleem oplossen.

Jan can any answer solve

'Jan can solve any problem.'

\footnotetext{
${ }^{8}$ In English, the phenomenon of subtrigging plays a role as well (LeGrand 1975; Dayal 1998). This is the phenomenon that free choice readings are more easily obtained when the any-expression is modified as in (i) below:

(i) Anyone with any sense had already left town (line from Bob Dylan, 'Lily, Rosemary and the Jack of Hearts')

(ii) *Anyone had already left town.
}

For Dutch enig, I have been unable to discern any subtrigging effects. For some crosslinguistic discussion of subtrigging effects, see Choi and Romero (2008). 
n. *Enig probleem zal opgelost worden.

Any problem will solved become

'Any problem will be solved.'

To the extent that the above examples are acceptable at all, they receive an existential, nonspecific reading. E.g. ( $4 \mathrm{~m})$ would read as 'Jan can solve some unspecified problem.' The universal reading of free-choice items is almost completely absent. This is strikingly different from the situation in Afrikaans, where universal readings of enig abound, no doubt due to the influence of English on that language (examples taken from the Internet):

a. Dit is ook van waarde vir enige student wat teologiese kennis

This is also of value for any student who theological knowledge soek

seeks

'This is also valuable to any student seeking theological knowledge'

b. Hy dink vir enige student is intervarsity die groot hoogtepunt van die He thinks for any student is intervarsity the big highlight of the jaar year

'He thinks intervarsity is the highlight of the year for any student'

For accounts of English any that postulate two separate uses, free-choice and NPI any, this state of affairs is not a problem: Dutch simply lacks one of the two uses. For unified accounts of any and similar indefinites, the Dutch situation is more surprising, and does not receive an easy solution.

\section{Historical developments}

Based on a corpus (cf. fn. 3) collected by the author of over 3000 occurrences of enig with singular count nouns (ambiguous cases of nouns that could be either count or mass were kept out of the database), a number of generalizations can be made regarding the diachrony of enig.

\subsection{Contexts in early modern texts}

When we look at older texts, even going back a mere 50 years will suffice to show that the distribution of enig has not always been what it is now. Besides the list in (3) above, the following types of environment are all attested in much larger numbers than they are today. (Hard-to-translate particles are glossed here simply as 'PRT'.)

\section{Modal contexts}

a. Men moest toch wel enige aanwijzing hebben. ${ }^{9}$ one ought PRT PRT some clue have

'One should have some clue.'

\footnotetext{
${ }^{9}$ Enquêtecommissie Regeringsbeleid 1940-1945, deel 4C-I, Verhoren: 7 [text from 1949].
} 
b. Ziedaar een paar vragen, waarop ik gaarne eenig antwoord zou see-there a few questions to-which I gladly some answer would willen ontvangen. ${ }^{10}$

want receive

'These are some questions for which I would like to receive an answer.' Imperatives

c. Kom daar maar eens om in enig ander land. ${ }^{11}$ come there PRT PRT for in some other country 'Try to find / get that in any other country.'

\section{Subjunctives}

d. En wie geen steenen kan aandragen storte [..] eenige gift in de And who no stones can to-carry throw some gift in the offerbus $^{12}$ offertory-box

'And who cannot carry bricks, should donate some gift in the offertorybox"

\section{Disjunctions}

e. [..] terwijl mijne oudste Zuster tusschen beide in den Bijbel of eenig while my oldest sister between both in the Bible or some stichtelijk boek las ${ }^{13}$ edifying book read '(..) while in between my oldest sister was reading in the Bible or some devotional book"

\section{Habitual sentences}

f. Vrienden en bekenden hadden de gewoonte om eenig deel van Friends and acquaintances had the custom to some part of een nieuw gebouw ${ }^{14}$ te versieren met een glas

a new building to decorate with a glass

'Friends and acquaintances had the habit to decorate some part of a new building with a glas'

Sporadic occurrences of "some or other" readings (10\% of about 300 "positive" occurrences):

g. Hy zondt enige Benden zyner Lyfwachten naar enig Binnen-landts

He sent some troups of-his bodyguards to some interior

Dorp, dat wat verre van de handt ligt. ${ }^{15}$

village that a-bit far from the hand lies

\footnotetext{
${ }^{10}$ De Navorscher, 1898: 11 .
}

${ }^{11}$ Nieuwsblad van het Noorden, 4 December 1999: 2.

${ }^{12}$ De Navorscher, 1871: 453.

${ }^{13}$ Willem van den Hull, Autobiografie [1778-1854], Verloren, Hilversum, 1996: 526. [text from late 1840 's].

${ }^{14}$ De Navorscher, 1860: 136.

${ }^{15}$ Boekzaal der geleerde Waerelt, 68, 1749: 534. 
'He sent some groups of his body-guards to some interior village, that is lying a bit out of the way."

h. Die de minste kennis van de manieren van Den Haag hebben, who the least knowledge of the manners of The Hague have, weeten, dat het een gerecipieerd gebruik is, dat Jonge Juffrouwen know, that it a received custom is, that young ladies nooit alleen in een Gezelschap komen, maar altyd verzeld van never alone in a gathering come but always accompanied by hunne Moeders, of eenige andere getrouwde Vrouw ${ }^{16}$ their mothers or some other married woman '[Even] those who have the least knowledge of the manners of The Hague, know, that it is a received custom, that young Ladies never appear alone in society, but always accompanied by their Mothers, of some other married Woman"

The examples in this list mostly fall within the category of nonveridical contexts (Zwarts 1995; Giannakidou 1997, 1999). Their defining characteristic is nonentailment of the truth of embedded propositions. More precisely, when XpY is true, and $\mathrm{X} \_\mathrm{Y}$ is a nonveridical environment, it does not follow that $\mathrm{p}$ is true. Typical nonveridical environments are negative environments of all kinds, questions, conditional clauses, etc., the classical hosts of standard negative polarity items, but in addition, the positive contexts in (6a-f) are also nonveridical. Giannakidou $(1997,1998,1999)$ in particular has made much of the interesting distribution of Greek indefinite pronouns and determiners of the kanenas-series, showing that they appear in nonveridical environments only. ${ }^{17}$ Some of her examples are given in (7):
a. Dhen idha kanenan fititi. not saw.1SG. any student 'I did not see any student.'
b. Elpizo na emine kanena komati. Hope.1SG. left any piece 'I hope there is a piece left.'

\footnotetext{
${ }^{16}$ Deductie voor Vrouwe S.A. van Haren, etc., Ferwerda, Leeuwarden, 1762: 23.

${ }^{17}$ The English WH the hell-construction also appears to behave as an NPI licensed by nonveridicality (cf. den Dikken and Giannakidou 2002). Compare:

(i) *John knows who the hell killed his dog.

(ii) Nobody knows who the hell killed John's dog.

(iii) John wants to know who the hell killed his dog.

While the difference between (i) and (ii) can be ascribed to the presence of negation in (ii), the difference between (i) and (iii) seems to depend on the nonveridical propositional-attitude verb want. This shows that nonveridicality is not solely relevant for indefinite NPIs. A comparison with other constructions involving the hell, e.g. examples such as get the hell out of here (which are positive polarity items, cf. Hoeksema and Napoli 2008) lends plausibility to the assumption that the polarity sensitivity of WH the hell is not a property of the hell itself, but of the entire construction $\mathrm{WH}$ the hell in which it takes part.
} 
c. Pijene se kanenan jatro!

Go to any doctor

[nonveridical imperative]

'Go to a doctor!'

Besides occurrences in nonveridical contexts, but less commonly, also nonspecific uses in veridical contexts can be found, even today. Here, the intended meaning seems to be indifference on the part of the speaker: "some X or other," as in examples g-h above. (Cf. also Haspelmath 1997; Farkas 2002; Kratzer and Shimoyama 2002; and Vlachou 2007 on non-specific and specific/unknown uses of indefinite pronouns.)

In Table 1 below, diachronic distributional developments are sketched. Note especially the rows for conditional and positive contexts (which show a strong decline) and those for negation, comparatives and clauses introduced by zonder 'without' (which show a strong increase).

The developments in Table 1 are complex and open to several interpretations. Some contexts are expanding, whereas others are shrinking or disappearing. Note that we are working with percentages, and so an increase in some category necessarily implies a decrease elsewhere and vice versa. I take the driving force behind the developments in this table to be the gradual disappearance of nonveridical occurrences. As a result, other categories that were important already, such as negation, complements of zonder 'without' and comparatives, became relatively more important. ${ }^{18}$ Let's assume, tentatively, that the gradual reduction of occurrences in conditional clauses is related to the general reduction of nonveridical environments, although conditional clauses are also among the standard examples of negative contexts (cf. e.g. Kadmon and Landman 1993). Note that in English, a conditional clause is a good host both for any and some in its 'some or other' sense:

a. If you meet any stray dog, shoot it.

b. If you meet some stray dog, shoot it. It may have rabies.

It is clear that the two sentences do not have the same meaning. While (8a) has universal force ('shoot every stray dog on sight'), (8b) does not. Moreover, (8a) is emphatic (Kadmon and Landman's strengthening) but (8b) is not. Occurrences of enig in the protasis of a conditional are, in the absence of emphasis marking, ambiguous between the emphatic any-type use and the nonemphatic some or other nonspecific use of English some. Consider the following example from the corpus:

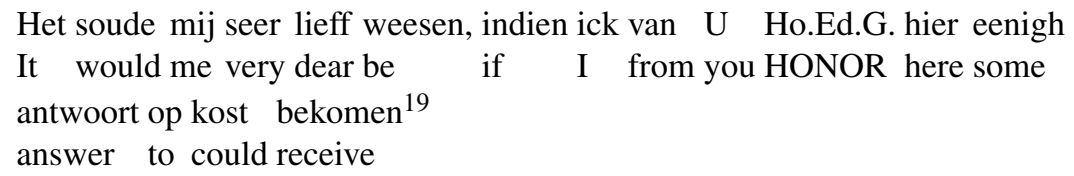

Het soude mij seer lieff weesen, indien ick van $U$ Ho.Ed.G. hier eenigh It would me very dear be if I from you HONOR here some antwoort op kost bekomen ${ }^{19}$ answer to could receive 'It would please me very much if I could receive some answer to this from you [HONORIFIC]'

\footnotetext{
${ }^{18}$ Because the data were hand-collected from a variety of sources, many of them not electronically available, it is not possible to provide useful information such as number of occurrences of enig per 1000 words, and the like.
}

${ }^{19}$ De Briefwisseling van Anthonie Heinsius 1702-1720, dl 3, 1704: 169. 
Table 1 ENIG-distribution of singular count occurrences [minus those of the collocation op enig moment ]

\begin{tabular}{lccccccc}
\hline Context & before & $1600-$ & $1700-$ & $1800-$ & $1900-$ & $1950-$ & $2000-$ \\
& 1600 & 1700 & 1800 & 1900 & 1950 & 2000 & 2009 \\
& $\mathrm{~N}=133$ & $\mathrm{~N}=238$ & $\mathrm{~N}=426$ & $\mathrm{~N}=721$ & $\mathrm{~N}=507$ & $\mathrm{~N}=790$ & $\mathrm{~N}=374$ \\
\hline Negation & $24 \%$ & $29 \%$ & $32 \%$ & $33 \%$ & $32 \%$ & $37 \%$ & $36 \%$ \\
Before & $0.8 \%$ & $2 \%$ & $0.5 \%$ & $0.3 \%$ & $1 \%$ & $1 \%$ & $0.5 \%$ \\
Conditional & $17 \%$ & $14 \%$ & $9 \%$ & $6 \%$ & $5 \%$ & $3 \%$ & $3 \%$ \\
Comparative & $11 \%$ & $5 \%$ & $6 \%$ & $10 \%$ & $15 \%$ & $16 \%$ & $21 \%$ \\
Comp of Eq. & - & $5 \%$ & $4 \%$ & $1 \%$ & $0.4 \%$ & $0.3 \%$ & - \\
Few / little & - & $0.4 \%$ & $0.5 \%$ & $0.4 \%$ & $0.2 \%$ & $0.1 \%$ & $0.5 \%$ \\
Hardly & $1 \%$ & $0.4 \%$ & $0.7 \%$ & $0.7 \%$ & $0.4 \%$ & $0.6 \%$ & $1 \%$ \\
Neg. pred. & $4 \%$ & $3 \%$ & $5 \%$ & $6 \%$ & $8 \%$ & $6 \%$ & $5 \%$ \\
Question & $9 \%$ & $5 \%$ & $7 \%$ & $7 \%$ & $8 \%$ & $9 \%$ & $5 \%$ \\
Seldom & $0.8 \%$ & - & $0.2 \%$ & $1 \%$ & $0.4 \%$ & $0.2 \%$ & $0.5 \%$ \\
Superlative & $2 \%$ & $1 \%$ & $0.7 \%$ & $1 \%$ & $0.4 \%$ & $0.9 \%$ & $0.3 \%$ \\
Too & - & - & $0.5 \%$ & $1 \%$ & $1 \%$ & $0.9 \%$ & $0.5 \%$ \\
Universal & $2 \%$ & $4 \%$ & $3 \%$ & $2 \%$ & $1 \%$ & $0.5 \%$ & $1 \%$ \\
Without & $15 \%$ & $13 \%$ & $15 \%$ & $14 \%$ & $18 \%$ & $20 \%$ & $22 \%$ \\
Positive & $\mathbf{1 5 \%}$ & $\mathbf{1 7 \%}$ & $\mathbf{1 4 \%}$ & $\mathbf{1 4 \%}$ & $\mathbf{8 \%}$ & $\mathbf{3 \%}$ & $\mathbf{2 \%}$ \\
\hline & & & & & & & $5 \%$ \\
\end{tabular}

It appears plausible that this example lends itself to translations with some, or some or other, as well as with any. So it could both have a nonemphatic (and nonveridical) reading 'I would like to receive an answer' and an emphatic reading 'it would please if I were to receive any answer at all'. Given the large drop in conditional environments in Table 1, it is likely that the non-strengthening, nonspecific uses represent the majority of occurrences in the early modern period, and that it is these unemphatic occurrences that disappear, in conditional clauses and elsewhere. The Dutch research dictionary Woordenboek der Nederlandsche Taal (WNT) (2010) notes in its entry for eenig that this expression, at least in its any-type usage, formerly could be used without stress, but that 'nowadays' (the volume in which the entry was published dates from 1916) it had to bear stress.

Also worth pointing out in the table is a jump in negative occurrences for enig between the $16^{\text {th }}$ and $17^{\text {th }}$ centuries: It is quite likely that this is due to the disappearance, in Dutch, of negative concord in the early-modern period, which in the $16^{\text {th }}$ century was still an important competitor of negation + enig, much like Middle English preferred Nobody did nothing etc. to Nobody did anything (cf. e.g. Hoeksema 1997; Postma 2002; Zeijlstra 2004). 
Finally, note the temporary drop in frequency of enig in comparatives of inequality, which seems due to the competition, at least in the written language, of comparatives of equality. After all, if one wanted to state that some woman is very beautiful, one could write, in early modern Dutch, that she is schoner dan enige vrouw 'more beautiful than any woman' or zo schoon als enige vrouw 'as beautiful as any woman.' Comparatives of inequality and comparatives of equality, although they differ in meaning, nonetheless should be viewed as semantic competitors from the point of view of the writer. Unlike English any or ever, in Dutch the use of enig in comparatives in equality disappeared from the written language, mirroring similar developments in the distribution of the negative polarity item ooit 'ever'. Other types of Dutch polarity-sensitive indefinites still appear in comparatives of equality, however, e.g. wie dan ook 'who then also = whoever, anyone':

a. Jan is groter dan wie dan ook.

Jan is larger than wie then also

'Jan is larger than anyone.'

b. Jan is net zo slim als wie dan ook.

Jan is just as smart as who then also

'Jan is just as clever as anyone.'

\subsection{Enig and its competitors}

The drop shown in Table 1 above in "positive" occurrences of enig in the period 1900-2009 coincides with several other developments in Dutch, such as the emergence of wh-items with NPI and Free Choice uses: wie dan ook 'who then too' meaning whoever, welke $N$ dan ook 'which then too' meaning whichever, wat dan ook 'what then too' meaning whatever etc., as well as the emergence of the complex determiner een of ander 'one or other = some or other', which is nowadays the preferred mode of expression for speaker-unknown or speaker-indifferent indefinites. ${ }^{20}$ In Table 2, some corpus data involving welk dan ook, a complex determiner, are compared to enig. ${ }^{21}$

Noteworthy in this table is not only the higher percentage of so-called positive occurrences for welk dan ook and especially any, but also the big differences in without-clauses and comparatives between the three determiners. These differences seem hard to explain in terms of traditional licensing conditions or in syntactic terms. There is no apparent reason why enig is that much more common in without-PPs than welk dan ook or any, and I assume that this is the result of a collocation effect: environments may favor certain items, which will then appear more frequently in these environments than might have otherwise been predicted. Such effects tend to be gradual,

\footnotetext{
${ }^{20}$ Indefinites of the $\mathrm{WH}+$ dan ook type are attested since the early 19th century. Een of ander is a bit older, and attested at least since the beginning of the 18th century.

${ }^{21}$ The percentages do not quite add up to $100 \%$ because some of the minor contexts were left out. The Dutch data were hand-collected by the author, the English data for any come in part from an Internet corpus compiled by the author in the early 1990's (cf. e.g. Hoeksema 1994 for other material from this corpus), and hand-coded by the author, and in part from books and newspapers. In the case of any, it should be noted that the distribution is highly sensitive to the status of the noun modified: e.g. free choice use is most common with singular count nouns, less so with plurals and mass nouns. The table does not distinguish among these cases.
} 
Table 2 Distribution of enig versus welk dan ook 'whichever' [post-1950 data] and any

\begin{tabular}{lccc}
\hline Context & Enig & Welk (dan) ook & $\begin{array}{l}\text { Any } \\
\mathrm{N}=1105\end{array}$ \\
& $\mathrm{~N}=652$ & $\mathrm{~N}=7307$ \\
\hline before-clause & $1 \%$ & $0.3 \%$ & $1 \%$ \\
comparative & $17 \%$ & $31 \%$ & $5 \%$ \\
comparative of equality & $0.3 \%$ & $3 \%$ & $1 \%$ \\
conditional & $3 \%$ & $3 \%$ & $7 \%$ \\
negation & $37 \%$ & $32 \%$ & $32 \%$ \\
negative predicate & $6 \%$ & $10 \%$ & $7 \%$ \\
question & $8 \%$ & $3 \%$ & $11 \%$ \\
without & $21 \%$ & $3 \%$ & $3 \%$ \\
positive (free choice) & $3 \%$ & $9 \%$ & $30 \%$ \\
\hline
\end{tabular}

rather than absolute, and current theories by and large deal with them by ignoring them (but see van der Wouden 1997 for an important exception). It seems reasonable to assume that collocation effects are directional in nature. For instance, enig does not select without-PPs as a favorite environment, but rather, without selects enig as a good indefinite to appear within its scope. Presumably, when a speaker formulates a sentence, the choice of without will be determined primarily by the meaning s/he intends to convey, whereas the choice from among enig, een, welk dan ook and other indefinite determiners is more or less free, given that they express roughly the same meaning. Collocation effects show that there are preferred choices, for a given environment, from the various options provided by the grammar.

The complex determiner een of ander 'one or other' has a rather different distribution than the items discussed so far. ${ }^{22}$ Unlike welk dan ook, but like polarity sensitive enig, it only combines with singular count nouns. Negated occurrences are fairly rare, ${ }^{23}$ and positive occurrences are the norm, whether in nonveridical or veridical contexts. Often, the use of een of ander signals either that the speaker finds the identity of the person or object irrelevant, or that he wants to distance himself from

\footnotetext{
${ }^{22}$ Actually, there are two variants of this expression: een of ander and de een of ander 'the one or other'. In spite of the presence of the definite article, the second variant is likewise indefinite, and behaves, as far as I have been able to ascertain, exactly like the first variant. For example, either variant can be used in existential contexts:

(i) $\quad$ Er was ( de) een of andere ruzie gaande.

There was some row going-on

'There was some row.'

${ }^{23}$ In a sample of 171 occurrences, I found 26 negated cases, or $15 \%$. Compared to enig or welk dan ook, this is not much. Mostly, it concerns either negation of matrix predicate, while een of ander appears in a subordinate clause, or cases of contrastive negation: ik ben je vrouw, niet een of andere sloerie 'I am your wife, not some bimbo.' Regular clause-mate negation does not appear possible: *Ik heb niet met een of andere student gesproken 'I did not talk to some student.' Clearly the matter deserves further attention.
} 
that person or object. ${ }^{24}$ Compare the examples in (11), in which I have paired off occurrences of een of ander with occurrences of English some:

a. Pick some number [irrelevant which one]

Kies een of ander getal

b. Is he some rancher from Texas or is he the President of the

Is hij een of andere rancher uit Texas of is hij de president van de

USA?

VS?

c. Every 15 minutes, some woman is raped on this

Elke 15 minuten wordt een of andere vrouw verkracht op deze planet.

planeet.

d. I don't want my daughter to go out with some

Ik wil niet dat mijn dochter uitgaat met een of andere jerk / *somebody

vlerk

In (11a) and (11b), the use of some indicates that the identity of the number or rancher in question is irrelevant or unknown. In (11c), we have some in the scope of a universal quantifier. The use of some to signal reference in a derogatory or pejorative way is strikingly different from the normal use of some. As illustrated in (11d), it is perfectly acceptable in negative sentences, quite unlike neutral some, which is a well-known positive polarity item (Klima 1964; Ladusaw 1979). And this is not because it has wide scope. Clearly, (11d) does not have to mean that there is some particular jerk that the speaker does not want his daughter to go out with.

To study the pejorative use of the indefinites in some more detail, I did a Googlesearch of combinations with a number of derogatory nouns, comparing them with combinations involving neutral nouns. The results are in Tables 3 and 4 and show three things: een of ander has a higher overall frequency than enig; een of ander is more common with derogatory nouns than with neutral nouns; enig is more common with neutral nouns than with derogatory ones. If we assume that the pejorative use of some really constitutes a separate use, and, more-over, assume that the same is true for een of ander, then the lower percentages of enig for derogatory nouns is simply the result of the fact that enig is neutral with respect to speaker-stance, and therefore dispreferred whenever there is a dedicated indefinite determiner for the expression of pejorative meaning. ${ }^{25}$

\footnotetext{
${ }^{24}$ The possibility of reference to objects that are speaker-unknown, or that the speaker does not want to identify is a clear point of similarity een of ander and the German irgend + INDEF series (irgendein, irgendwas, irgendwer etc., cf. Kratzer and Shimoyama 2002). Nonetheless, there are some important differences as well, such as the lack of free choice readings in imperatives. In particular, (11a) has a nonspecific indefinite reading, but not a quasi-universal reading compare to Pick any number. Hence the analysis proposed by Kratzer and Shimoyama, using alternative semantics along the lines of Hamblin (1973), cannot be carried over straight-forwardly to een of ander.

${ }^{25}$ The use of Google for linguistic purposes has become rather a common-place practice, especially when the goal is to find examples of rare phenomena (see for instance Condoravdi 2010), but sev-
} 
Table 3 Derogatory nouns-Google counts

Table 4 Neutral nouns

\begin{tabular}{llcl}
\hline Noun & Translation & + een of ander & + enig \\
\hline Halve gare & Halfwit & 72 & - \\
Oen & Nut & 45 & - \\
Sukkel & Loser & 147 & - \\
Klootzak & Asshole & 111 & - \\
Snol & Tramp & 41 & - \\
Wijf & Bitch & 86 & 1 \\
Total & & 502 & 1 \\
\hline
\end{tabular}

\begin{tabular}{llcc}
\hline Noun & Translation & + een of ander & + enig \\
\hline Nederlander & Dutchman & 29 & 4 \\
Auto & Car & 59 & 6 \\
Vrouw & Woman & 154 & 13 \\
Huis & House & 146 & 35 \\
Dier & Animal & 212 & 81 \\
Total & & 600 & 139 \\
\hline
\end{tabular}

In Table 5, a general overview of the options is given. Note that the table is somewhat misleading in that the contexts and uses are orthogonal categories. For instance, a pejorative use can be found in veridical as well as negative or positive but nonveridical contexts. A three-dimensional table would have been more appropriate, but is more difficult to show on paper.

Another point worth making concerns the distribution of een of ander. While this expression can be used in all contexts, including episodic past tense contexts which are completely off-limits for expressions like any or singular-count enig, it appears to be far more frequent in negative and other nonveridical contexts. In a small sample of 113 occurrences, collected from books and newspapers, I found that 95 , or $84 \%$, were in nonveridical contexts, and 18 , or $16 \%$, in veridical contexts where the speaker was

eral linguists, including one of the reviewers of this paper, have warned against the use of Google counts as evidence for usage frequency (cf. also various postings on Mark Liberman's Language Loghttp://languagelog.ldc.upenn.edu/nll). Alternative sources of texts, such as newspaper corpora are not large enough, however, when it comes to combinations of not so frequent expressions-for instance, LexisNexis provided from dozens of Dutch newspapers over a period of 18 or so years only a meagre 5 instances of the combination een of andere halve gare 'some half-wit', and similarly disappointing yields for the other nouns in Table 3. Therefore I have decided to stick by the Google counts as a rough estimation of usage frequency. The numbers given in Tables 3 and 4 do not give the total number of hits as estimated by Google, but only the actual number of hits provided by Google. This means the largest numbers (those in the rightmost column) are greatly underestimated, but for our purpose, this should not matter, given that the main differences between Table 3 and Table 4 lie in the other columns. The Google counts reported here are from August 13, 2008. An earlier version of this paper used figures from spring 2007, which were different, obviously, but showed the same overall pattern: a serious difference between derogatory and neutral nouns when it comes to the choice between enig and een of ander. Hits for the string de enige 'the only' were for obvious reasons not included among those for enig. 
either unaware of or indifferent to the identity of the individual or object described. Not included in this sample were cases of the highly frequent combination op (de) een of andere manier 'in some way', which does not share this rather slanted distribution. Presumably, this reflects the different ontological status of manners vis á vis objects or persons with respect to individuation. Many of the nonveridical contexts were irrealis contexts created by modals or propositional attitude verbs as wish, hope, seek, imagine and try. It is likely that the rapid emergence of een of ander (starting in the $18^{\text {th }}$ century) has pushed out enig from such contexts.

\subsection{Special cases}

A striking feature of enig is the fact that it appears quite often in combination with the adjective ander, the Dutch word for other. For the period 1950-2009, this combination accounts for somewhat more than 5\% of all occurrences of enig, and it is interesting to note the strong effect that the presence of ander has on the distribution of enig. Table 6 below shows two things: an enormous disparity in the category comparative, and an equally spectacular one in the category without. Other changes, like the drop in negation environments, probably just reflect a relative decline due to the expansion of comparative-triggered occurrences.

In the case of the comparative, we seem to be looking at a logical nicety of natural language. Normally, when I make a quantified statement, certain members of the domain are excluded for pragmatic reasons (cf. the discussion in Hendriks and de Hoop 2001). When I say 'I can see everybody from here quite well', I do not mean

Table 5 Contexts and uses of 6 indefinite determiners

\begin{tabular}{lllllll}
\hline Context/use & Any & Some & A(n) & Enig (SG count) & Een of Ander & Een \\
\hline Veridical (neutral) & $*$ & $\checkmark$ & $\checkmark$ & $*$ & $\checkmark$ & $\checkmark$ \\
Negative (neutral) & $\checkmark$ & $*$ & $\checkmark$ & $\checkmark$ & $\checkmark$ & $\checkmark$ \\
Nonveridical positive (neutral) & $*$ & $\checkmark$ & $\checkmark$ & $*$ & $\checkmark$ & $*$ \\
Generic/Free choice & $\checkmark$ & $*$ & $\checkmark$ & $*$ & $\checkmark$ & $\checkmark$ \\
Pejorative & $*$ & $\checkmark$ & $*$ & $*$ & $\checkmark$ & $*$ \\
Reference irrelevant & $*$ & $\checkmark$ & $*$ & $*$ & $*$ \\
\hline
\end{tabular}

Table 6 Enig ander "any other" compared to enig without ander

\begin{tabular}{lcc}
\hline Context & +ander & -ander \\
& $\mathrm{N}=194$ & $\mathrm{~N}=911$ \\
\hline comparative & $59 \%$ & $7 \%$ \\
conditional & $3 \%$ & $3 \%$ \\
negation & $31 \%$ & $39 \%$ \\
neg. predicate & $0.5 \%$ & $6 \%$ \\
question & $1 \%$ & $9 \%$ \\
without & $1 \%$ & $25 \%$ \\
positive & $2 \%$ & $3 \%$ \\
\hline
\end{tabular}


to include myself, for example. The same can be said for the statement 'Chomsky is a better dancer than any linguist'. Here, we naturally assume that the set of linguists under consideration does not include Chomsky, or else we would be making the paradoxical claim that Chomsky is a better dancer than himself. Most of the time we do this kind of pragmatic restriction of the domain of quantification almost automatically, but the collocation enig ander, used in the comparative, offers a semantic solution to this problem. I propose that this is the reason behind the big difference in the category comparative in Table 6.

The big drop in without-phrases is rather harder to account for. It will have to be explained somehow, as it appears quite unlikely that it is a mere statistical fluctuation.

Another contextual effect I want to point out is the effect of disjunction on the distribution of polarity items. In Table 7 below, I have brought together some corpus data involving the Dutch WH-indefinites wie dan ook, wat dan ook, welke dan ook etc., comparing uses as part of a disjunction with all other uses. Here, the main thing to note is the increase of negation-environments whenever the item is inside a disjunction. This effect is also found for English any, on a slightly smaller scale. One may also find this type of distributional effect among polarity items that are themselves disjunctions, such as make head or tails of something, or in any way, shape or form, or for love or money. All of them have a pretty strong preference for purely negative environments, more so than any or ever, for example.

Table 8 below shows what happens to enig ander in disjunctive contexts. In particular, we are looking at the difference between sentences such as (12a) and (12b):

a. Jan werkte harder dan enige andere student.

Jan worked harder than any other student

'Jan worked harder than any other student.'

b. Jan werkte harder dan Fred of enige andere student.

Jan worked harder than Fred or any other student

'Jan worked harder than Fred or any other student.'

Here, the raw numbers are low, so most percentages should be viewed cum grano salis. However, what cannot be ignored here is the sudden disappearance of the cat-

Table 7 Disjunctions: WH dan ook (wie dan ook, wat dan ook, etc.) and ANY

\begin{tabular}{lcccc}
\hline Context & $\begin{array}{l}\text { WH dan ook } \\
\text { +DISJ (N=149) }\end{array}$ & $\begin{array}{l}\text { WH dan ook } \\
- \text { DISJ (N=1325) }\end{array}$ & $\begin{array}{l}\text { ANY + DISJ } \\
(\mathrm{N}=131)\end{array}$ & $\begin{array}{l}\text { ANY - DISJ } \\
(\mathrm{N}=5616)\end{array}$ \\
\hline comparative & $3 \%$ & $40 \%$ & $2 \%$ & $4 \%$ \\
compar. of equality & - & $3 \%$ & $1 \%$ & $1 \%$ \\
conditional & $3 \%$ & $3 \%$ & $8 \%$ & $7 \%$ \\
negation & $50 \%$ & $29 \%$ & $44 \%$ & $30 \%$ \\
negative predicate & $5 \%$ & $7 \%$ & $5 \%$ & $6 \%$ \\
universal & $1 \%$ & $2 \%$ & $2 \%$ & $0.5 \%$ \\
question & $7 \%$ & $2 \%$ & $7 \%$ & $12 \%$ \\
without & $9 \%$ & $4 \%$ & $2 \%$ & $2 \%$ \\
positive & $15 \%$ & $7 \%$ & $29 \%$ & $34 \%$ \\
\hline
\end{tabular}


Table 8 of enig ander 'or any other'

\begin{tabular}{lcc}
\hline Context & $\%$.. of enig ander... & \% enig ander \\
& $\mathrm{N}=23$ & $\mathrm{~N}=194$ \\
\hline comparative & - & $59 \%$ \\
conditional & $9 \%$ & $3 \%$ \\
negation & $65 \%$ & $31 \%$ \\
neg. predicate & $9 \%$ & $0.5 \%$ \\
question & $9 \%$ & $1 \%$ \\
without & $4 \%$ & $1 \%$ \\
positive & $4 \%$ & $2 \%$ \\
\hline
\end{tabular}

egory comparative. This is strikingly similar to the situation in Table 7, which also shows a plunging percentage of occurrences of the WH-items in comparative contexts when they are embedded in a disjunction.

\subsection{In conclusion}

Its gradual disappearance from positive, mainly nonveridical, uses has turned enig, at least in combinations with singular count nouns, into a negative polarity item. This change is interesting for several reasons. First, it shows that nonveridicality is not just an exotic property of some Greek pronouns: Germanic languages, which so far had seemed rather different from Greek in not appearing to have pronouns sensitive to nonveridicality, also appear to show sensitivity to this property. Sensitivity to nonveridicality is of course a sign that a pronoun or determiner is used in a nonreferring way. Obligatory nonreferentiality may lead to a pronoun being used only in nonveridical, including negative, contexts. In negative contexts, emphatic use of items may develop into a special use with different distributional properties than nonemphatic, nonstressed occurrences. For Greek kanenas, it was shown by Veloudis (1982) and Giannakidou (1997) that stressed occurrences have a far more limited distribution, being acceptable only in negative sentences, the scope of xoris 'without', and prin 'before.' For English any, the importance of stress and focus was forcefully argued for by Sahlin (1979) and Krifka (1995). Finally, Hoeksema (1999) argued that Dutch ooit 'ever' has developed two prosodically-distinct uses, one allowing for comma intonation, the other for emphatic lengthening of the vowel. The latter is a negative polarity item, the former is not. Let us therefore assume that in certain environments, such as negation, the possibility of stress changed enig from an expression primary used to express nonreferentiality, to an expression of emphasis, much like Greek stressed kanenas, and with an almost identical distribution (comparatives being the main difference). The main difference with the Greek situation is that the two types of kanenas remained equally grammatical, whereas the nonreferential, nonemphatic form of enig has virtually disappeared.

\section{Conclusions and outlook}

On the basis of diachronic data, I have argued that Dutch enig changed from a nonreferential indefinite found primarily in nonveridical contexts into a regular negative- 
polarity item restricted to downward-entailing contexts. The role of stress is hypothesized to have played a role in this process. The distribution of polarity items tends to be fairly unstable, as these items are prone to develop sometimes idiosyncratic collocation restrictions (van der Wouden 1997; Sailer and Richter 2002) and therefore it appears, at any given moment in time, to be rather messy. Detailed historical and synchronic corpus study of usage patterns will be needed to further disentangle and expose the general forces behind the chaos.

Meanwhile, some general ideas have emerged already as fruitful hypotheses regarding the relation between polarity items and their distribution. For scalar expressions, the prevailing idea is that their function is pragmatic strengthening and that their distribution is somehow determined by this function (cf. Kadmon and Landman 1993 and much subsequent work). For weak polarity items that require nonveridical environments, the central factor in determining this distribution seems to be a requirement of nonreferentiality: these indefinites can only be guaranteed not to refer to anything in nonveridical environments. One may wonder, at this point, whether polarity items that are licensed by nonveridicality are necessarily indefinite pronouns or determiners. The answer is no (cf. also fn. 18). Oosterhof (2004) has pointed out that the Dutch verb doorgaan 'go through, continue' has a use where it means 'to take place as scheduled.' This use, he argues, is restricted, by and large, to nonveridical contexts. ${ }^{26}$ Compare:

a. Het feest ging niet door.

The party went not on

'The party did not take place.'

b. Het feest ging door.

The party went on

'The party continued.'

c. Jan hoopte dat het feest door zou gaan.

Jan hoped that the party on would go

'Jan hoped the party would take place / Jan hoped the party would continue.'

Here the pertinent factor is, once more, nonreferentiality, but now at the level of events: events that do not take place do not exist. It would be of some interest for the typology of negative polarity items to identify more types of expressions in a variety of languages that likewise show a restriction to nonveridical contexts.

The general treatment of distributional changes among indefinites in Jäger (2010) prompts the question of whether the changes documented here for enig fit within that framework. To summarize, Jäger postulates three types of indefinites, and two features to classify them. Normal and PPI-indefinites are unmarked, polarity items are [+affective] and n-indefinites (n-words) are [+affective, + neg]. Only plus values are

\footnotetext{
${ }^{26}$ Out of the 166 occurrences of this verb, in the intended reading 'take place', in my material, there are 120 from negative sentences, 9 from questions, 8 from conditional clauses, 2 are licensed by restrictive adverbs (type only) and 1 is in the complement of a negative predicate. The 26 remaining positive occurrences are almost all either cases of denial of a negative presupposition (het feest ging wél door 'the party DID take place') or nonveridical cases similar to (13c). Only three cases are positive and veridical.
} 
allowed for these features. The feature [+neg], finally, implies [+affective], and so only three types of indefinites are allowed. N-words are viewed as polarity-sensitive indefinites, triggered by (possibly covert) negation (see also Penka and von Stechow 2001; Zeijlstra 2004; Penka 2007). This system is simple and elegant, and capable of describing a great many attested changes in the use of indefinites in terms of the addition or loss of features. However, it is not, as yet, fine-grained enough to distinguish among weak polarity-items such as early-modern Dutch enig, from polarity items with a more restricted distribution, such as English ever, or present-day Dutch enig. Clearly, more features are needed, not only to distinguish more subclasses of negative-polarity items, but also to separate positive-polarity items like some from neutral indefinites like $a(n)$. Whether a marginally larger set of features will suffice to characterize the distributional patterns of the various items, is highly doubtful, however. Languages like Dutch, English or German have large numbers of indefinites whose distributions vary in all sorts of ways. We have seen several instances of such variation in this paper. For instance, the Dutch polarity-sensitive indefinite wie dan ook 'anyone, whoever it may be' is found in comparatives of equality, but enig 'any', which used to occur in that context as well, has disappeared from it. Some indefinites abound in disjunctions, others do not (cf. the discussion of ook maar iets versus zelfs maar iets in Hoeksema and Rullmann 2001). Quite often, this is due to strong collocational effects (cf. the discussion of enig + ander 'any other' above). My conclusion from this is that polarity items are far more intricately connected to fine details of syntactic contexts than is commonly assumed.

I hope that this paper will inspire others to look in more detail at the various polarity items in their language. Typological work such as that of Haspelmath (1997) suggests that many languages have various series of indefinites which are in competition with one another. Fine-grained corpus analysis will help to shed light on the complex distributional patterns to which this competition gives rise.

Open Access This article is distributed under the terms of the Creative Commons Attribution Noncommercial License which permits any noncommercial use, distribution, and reproduction in any medium, provided the original author(s) and source are credited.

\section{References}

Anscombe, G. E. M. 1964. Before and after. The Philosophical Review 74: 3-24.

Atlas, Jay D. 1996. Only noun phrases, pseudo-negative generalized quantifiers, negative polarity items and monotonicity. Journal of Semantics 23: 265-332.

Baker, C. Lee. 1970. Double negatives. Linguistic Inquiry 1: 169-186.

Borkin, Ann. 1971. Polarity items in questions. In Papers from the seventh regional meeting of the Chicago Linguistic Society, 53-62. Chicago: Chicago Linguistic Society.

Carlson, Gregory N. 1981. The distribution of free-choice any. In Papers from the seventeenth regional meeting of the Chicago Linguistic Society, 8-23. Chicago: Chicago Linguistic Society.

Chierchia, Gennaro. 2006. Broaden your views. Implicatures of domain widening and the "Logicality" of language. Linguistic Inquiry 37: 535-590.

Choi, Jinyoung, and Maribel Romero. 2008. Rescuing existential free choice items in episodic sentences. In Empirical issues in syntax and semantics, Vol. 7, eds. Olivier Bonami and Patricia Cabredo Hofherr, 77-98. Available at: http://www.cssp.cnrs.fr/eiss7.

Condoravdi, Cleo. 2010. NPI licensing in temporal clauses. Natural Language \& Linguistic Theory 28: 4.

Dayal, Veneeta. 1998. Any as inherently modal. Linguistics and Philosophy 21: 433-476. 
de Swart, Henriëtte. 2010. Expression and interpretation of negation. An OT typology. Vol. 77 of Studies in Natural Language and Linguistic Theory, Dordrecht: Springer.

den Dikken, Marcel. 2002. Direct and indirect polarity item licensing. Journal of Comparative Germanic Linguistics 5: 35-66.

den Dikken, Marcel. 2006. Parasitism, secondary triggering and depth of embedding. In Crosslinguistic research in syntax and semantics: Negation, tense, and clausal architecture, eds. Raffaella Zanuttini, Hector Campos, Elena Herburger, and Paul Portner. Georgetown, Washington: Georgetown University Press.

den Dikken, Marcel, and Anastasia Giannakidou. 2002. From hell to polarity: "Aggressively non-D-linked" wh-phrases as polarity items. Linguistic Inquiry 33: 31-61.

Farkas, Donka. 2002. Varieties of Indefinites. In Proceedings of SALT, Vol. 12, ed. Brendan Jackson, 5983. Ithaca: Cornell University.

Fauconnier, Gilles. 1978. Implication reversal in a natural language. In Formal semantics and pragmatics for natural languages, eds. Franz Guenthner and S. J. Schmidt, 289-301. Dordrecht: Reidel.

Gajewski, Jon. 2008. Licensing strong NPIs. In Proceedings of the 31st annual Penn linguistics colloquium, 162-176.

Giannakidou, Anastasia. 1997. The landscape of polarity items. PhD dissertation. University of Groningen.

Giannakidou, Anastasia. 1998. Polarity sensitivity as (non)veridical dependency. AmsterdamPhiladelphia: John Benjamins.

Giannakidou, Anastasia. 1999. Affective dependencies. Linguistics and Philosophy 22 (4): 367-421.

Giannakidou, Anastasia. 2006. Only, emotive factives, and the dual nature of polarity dependency. Language 82: 575-603.

Hamblin, Charles L. 1973. Questions in Montague English. Foundations of Language 10: 41-53.

Haspelmath, Martin. 1997. Indefinite pronouns. Oxford: Oxford University Press.

Heim, Irene. 1984. A note on polarity sensitivity and downward entailingness. North East Linguistics Society 14: 98-107.

Hendriks, Petra, and Helen de Hoop. 2001. Optimality theoretic semantics. Linguistics and Philosophy 24 (1): $1-32$.

Hoeksema, Jack. 1986. Monotonie en Superlatieven. In Proeven van taalwetenschap, eds. Cor Hoppenbrouwers, Joop Houtman, Ineke Schuurman, and Frans Zwarts, 38-49. Groningen: Nederlands Instituut RUG.

Hoeksema, Jack. 1994. On the grammaticalization of negative polarity items. Proceedings of the Berkeley Linguistics Society 20: 273-282.

Hoeksema, Jack. 1997. Negation and negative concord in Middle Dutch. In Negation and Polarity, eds. Danielle Forget, Paul Hirschbühler, France Martineau, and María Luisa Rivero, 139-156. Amsterdam: John Benjamins.

Hoeksema, Jack. 1999. Aantekeningen bij ooit, deel 2: De opkomst van niet-polair ooit. Tabu 29 (4): $147-172$.

Hoeksema, Jack. 2007. Parasitic licensing of negative polarity items. Journal of Comparative Germanic Linguistics 10 (3): 163-182.

Hoeksema, Jack, and Henny Klein. 1995. Negative predicates and their arguments. Linguistic Analysis 25: $146-180$.

Hoeksema, Jack, and Donna-Jo Napoli. 2008. Just for the hell of it: A comparison of two taboo-term constructions. Journal of Linguistics 44 (2): 347-378.

Hoeksema, Jack, and Hotze Rullmann. 2001. Scalarity and polarity. A study of scalar adverbs as polarity items. In Perspectives on negation and polarity items, eds. Jack Hoeksema, Hotze Rullmann, Víctor Sánchez-Valencia, and Ton van der Wouden, 129-171. Amsterdam-Philadelphia: John Benjamins.

Horn, Laurence R. 1989. A natural history of negation. Chicago: University of Chicago Press.

Horn, Laurence R. 2000a. Pick a theory (not just any theory). Indiscriminatives and the free-choice indefinite. In Studies in negation and polarity, eds. Laurence Horn and Yasuhiko Kato, 147-192. Oxford: Oxford University Press.

Horn, Laurence R. 2000b. Any and (-)ever. Free choice and free relatives. Proceedings of IATL 15: 71-111.

Horn, Laurence R. 2005. Airport '86 revisited: Toward a unified indefinite any. In Reference and quantification: the partee effect, eds. Gregory N. Carlson and Francis Jeffry Pelletier, 179-205. Stanford: CSLI.

Israel, Michael. 1996. Polarity sensitivity as lexical semantics. Linguistics and Philosophy 19: 619-666.

Israel, Michael. 1998. Ever: Polysemy and polarity sensitivity. In Linguistic Notes from La Jolla 19. 
Israel, Michael. 1999. Some and the pragmatics of indefinite construal. Proceedings of the Berkeley Linguistics Society 25: 169-182.

Jäger, Agnes. 2010. Anything is nothing is something. On the diachrony of polarity types of indefinites. Natural Language \& Linguistic Theory 28: 4.

Kadmon, Nirit, and Fred Landman. 1993. Any. Linguistics and Philosophy 16 (4): 353-422.

Kiparsky, Paul. 1973. Elsewhere in phonology. In A festschrift for Morris Halle, eds. Stephen Anderson and Paul Kiparsky, 93-106. New York: Holt, Rinehart and Winston.

Klima, Edward S. 1964. Negation in English. In The structure of language, eds. Jerry A. Fodor and Herrold Katz. Prentice Hall: Englewood Cliffs.

Kratzer, Angelika, and Junko Shimoyama. 2002. Indeterminate pronouns: The view from Japanese. In Proceedings of the 3rd Tokyo conference on psycholinguistics, ed. Yukio Otsu, 1-25. Tokyo: Hituzi Syobo.

Krifka, Manfred. 1995. The semantics and pragmatics of polarity items. Linguistic Analysis 25: $209-257$.

Ladusaw, William A. 1979. Polarity sensitivity as inherent scope relations. Doctoral dissertation. University of Texas at Austin.

Lahiri, Utpal. 1998. Focus and negative polarity in Hindi. Natural Language Semantics 6: 57-125.

Landman, Fred. 1991. Structures for semantics. Kluwer: Dordrecht.

LeGrand, Jean. 1975. Or and Any: The semantics and syntax of two logical operators. Dissertation, University of Chicago.

Linebarger, Marcia. 1981. The grammar of negative polarity. Doctoral dissertation, Massachusetts Institute of Technology.

Oosterhof, Albert. 2004. Polariteitsgevoeligheid van doorgaan ('gehouden worden'). Tabu 33 (3/4): 131150.

Penka, Doris. 2007. Negative indefinites. Doctoral Dissertation, University of Tübingen.

Penka, Doris, and Arnim von Stechow. 2001. Negative Indefinita unter Modalverben. In Modalität und Modalverben im Deutschen, eds. Reimar Müller and Marga Reis, 263-286. Hamburg: Helmut Buske.

Pereltsvaig, Asya. 2006. Negative polarity items in Russian and the 'Bagel Problem'. In Negation in Slavic, eds. Adam Przepiorkowski and Sue Brown, 153-178. Bloomington: Slavica Publishers.

Postal, Paul M. 2000. The Ohio lectures on squat. Manuscript, New York University.

Postal, Paul M. 2005. Suppose (if only for an hour) that negative polarity items are negation-containing phrases. Manuscript, New York University.

Postma, Gertjan. 2002. De enkelvoudige clitische negatie in het Middelnederlands en de Jespersen-cyclus. Nederlandse Taalkunde 7: 44-82.

Progovac, Ljiljana. 1994. Negative and positive polarity: A binding approach. Cambridge: Cambridge University Press.

Sahlin, Elisabeth. 1979. Some and any in spoken and written English. Uppsala: Almqvist and Wiksell.

Sailer, Manfred, and Frank Richter. 2002. Not for love or money: Collocations! In Proceedings of formal grammar 2002, eds. Gerhard Jäger, Paola Monachesi, Gerald Penn, and Shuly Wintner, 149-160.

Sánchez-Valencia, Víctor, Ton van der Wouden, and Frans Zwarts. 1994. Polarity, veridicality and temporal connectives. In Proceedings of the ninth Amsterdam colloquium, 587-606.

Szabolcsi, Anna. 2004. Positive polarity-negative polarity. Natural Language \& Linguistic Theory 22 (2): 409-452.

van der Wouden, Ton. 1997. Negative contexts. Collocation, polarity and multiple negation. London: Routledge.

van Ommen, Sandrien, Dicky Gilbers, and Jack Hoeksema. 2007. Heeeeele lange vocalen: Een onderzoek naar emfatische rekking. Tabu 36 (1/2): 39-64.

van Rooij, Robert. 2003. Negative polarity items in questions: Strength as relevance. Journal of Semantics 20: 239-274.

Veloudis, Jannis. 1982. Negation in modern Greek. PhD dissertation, University of Reading.

Vlachou, Evangelia. 2007. Free choice in and out of context. PhD dissertation, Sorbonne and University of Utrecht.

von Fintel, Kai. 1999. NPI licensing, Strawson entailment, and context dependencies. Journal of Semantics 16: $97-148$.

Woordenboek der Nederlandsche Taal (WNT) 2010. eds. Mark de Vries, Lammert Allard te Winkel, et al. ('s Gravenhage: Nijhoff, 1882-2000). [Also available on cd-rom]. 
Zeijlstra, Hedde. 2004. Sentential negation and negative concord. Doctoral dissertation, University of Amsterdam.

Zwarts, Frans. 1981. Negatief Polaire Uitdrukkingen I. Glot 4 (1): 35-132.

Zwarts, Frans. 1995. Nonveridical contexts. Linguistic Analysis 25: 286-312.

Zwarts, Frans. 1998. Three types of polarity. In Plurality and quantification, eds. Fritz Hamm and Erhard Hinrichs, 177-238. Kluwer: Dordrecht. 